\title{
Synthetic peptides in the diagnosis of exocrine pancreatic insufficiency in animals
}

\author{
A. R. IMONDI, R. P. STRADLEY, AND R. WOLGEMUTH \\ From the Division of Biomedical Research, Warren-Teed Pharmaceuticals, Inc, Columbus, Ohio
}

SUMMARY A new approach in the diagnosis of exocrine pancreatic insufficiency has been evaluated in animals. The method involves the oral administration of a chymotrypsin-labile peptide which contains p-aminobenzoic acid (PABA) as a tracer group. In the small bowel in the presence of chymotrypsin, the PABA is split from the peptide and is rapidly absorbed. The amount of PABA (as total aromatic amines) recovered in the urine during the six hours after the dose is used as an index of exocrine pancreatic function. The procedure has been shown to be reliable in detecting surgically induced pancreatic insufficiency in rats, swine, and dogs.

A new tubeless test for exocrine pancreatic insufficiency was suggested to us by Dr Norton J. Greenberger. Preliminary studies showed the test to be highly reliable in detecting pancreatic deficiency in animals (Imondi, Stradley, Wolgemuth, and Brown, 1971). In this procedure a synthetic peptide composed of an aromatic amino acid and a readily absorbable tracer group, p-aminobenzoic acid (PABA), is administered orally. In the presence of chymotrypsin, the peptide is split with the liberation of PABA which is absorbed from the gut, undergoes conjugation, and is excreted in the urine. The amount of PABA (aromatic amines) in the urine is used as a measure of exocrine pancreatic function.

\section{Methods}

\section{ANIMALS}

Exocrine pancreatic insufficiency was produced surgically in male and female Sprague-Dawley rats (200-400 g), mongrel dogs $(5-10 \mathrm{~kg})$, and West African Guinea swine $(8-20 \mathrm{~kg})$. The rats were anaesthetized with ether and the common bile duct was doubly ligated and sectioned near its attachment to the duodenum. These animals are referred to in this paper as B-PDL rats to denote the exclusion of both bile and pancreatic juice from the intestine. These rats, in which bile was excluded from the intestine, were prepared by ligating the bile duct just below the hilus of the liver (Grossman, 1958). An 18-hour recovery period was allowed before administering the peptide to the rats. Pancreatic Received for publication 2 June 1972. duct ligation and section (Pekas, Hays, and Thompson, 1964) was performed in the swine under halothane anaesthesia. These animals, referred to as PDL, were allowed a minimum of three postoperative recovery days before drug testing. Dogs were made exocrine pancreatic deficient by ligating the pancreatic ducts and separating the pancreas from the duodenum with omentum (Grossman, 1962). Studies in dogs were not begun until at least one week after surgery. The surgical procedures did not significantly affect the ability of the animals to absorb and excrete orally administered PABA.

TEST PROCEDURE in vivo

Animals to be tested were fasted overnight. The test peptide was administered orally as an aqueous solution of its sodium salt. After dosing the animals were confined individually to metabolism cages. Food was withheld, but water was allowed ad libitum. Urine collections were made at the times stated in each experiment. The total aromatic amine concentration of the urine was determined by the Bratton-Marshall method as modified by Smith, Finkelstein, Aliminosa, Crawford, and Graber (1945). Background urinary aromatic amines were found to be negligible and were not corrected for in these studies. Since the bulk of the urinary aromatic amines was derived from orally administered peptidePABA, the term PABA will be used throughout to denote aromatic amines.

PEPTIDES

All test peptides used in these studies were synthesized 
by Dr Peter de Benneville of the Rohm and Haas Company, Philadelphia. Each peptide contained an aromatic amino acid, a carboxyl terminal PABA, and an $\mathrm{N}$-terminal blocking group. The peptides were not water soluble in the acid form but were highly soluble as their sodium salts. Total PABA in each peptide preparation was determined after refluxing with $6 \mathrm{~N} \mathrm{HCl}$. Unhydrolyzed preparations contained less than $1 \%$ free PABA.

HYDROLYSIS OF PEPTIDES in vitro WITH CHYMOTRYPSIN

The rate of PABA release in the presence of chymotrypsin was determined using a substrate mixture of $0.5 \mathrm{mM}$ peptide, $0.1 \mathrm{M}$ tris $(p \mathrm{H} 7.8)$ and $0.08 \mathrm{M}$ $\mathrm{CaCl}_{2}$. Two mg chymotrypsin (Wilson Laboratories, Chicago) dissolved in $1 \mathrm{ml} \mathrm{mM} \mathrm{HCl}$ was added to $25 \mathrm{ml}$ of the substrate. The reaction was carried out at $25^{\circ} \mathrm{C}$, and at selected intervals between 0 and 30 minutes $1 \mathrm{ml}$ aliquots of the reaction mixture were removed and added to $9 \mathrm{ml}$. $2 \mathrm{~N} \mathrm{HCl}$. Free PABA was determined using the Bratton-Marshall method for aromatic amines.

\section{Results}

The data presented in Table I show that the amount

\begin{tabular}{llcc}
\hline Species & Number $^{1}$ & $\begin{array}{l}\text { Dose of PABA } \\
(\mathrm{mg} / \mathrm{kg})\end{array}$ & $\begin{array}{l}\text { Urinary PABA } \\
(\mathrm{mg} / 6 \text { hours })\end{array}$ \\
\hline Rat & 4 & 0 & $0.03 \pm 0$ \\
& 4 & 1 & $0.32 \pm 0.03$ \\
& 3 & 10 & $3.72 \pm 0.48$ \\
Swine & 1 & 100 & 33.70 \\
& 4 & 0 & $1.16 \pm 0.31$ \\
& 4 & 1.25 & $9.73 \pm 1.65$ \\
& 4 & 2.50 & $24.93 \pm 6.15$ \\
& 4 & 5.00 & $35.91 \pm 8.11$
\end{tabular}

Table I Urinary excretion of para-amino benzoic acid $(P A B A)$ following oral administration

${ }^{1}$ Number of groups (three rats/group) and number of swine per treatment 'Mean \pm SEM of PABA excreted during the six hours following oral doses of sodium PABA was directly proportional to the dose of PABA in both the rats and the swine. There was generally less variation in PABA recoveries when a six-hour urine collection period was compared with shorter collection periods. Urinary PABA levels were approximately 100 times background when $10 \mathrm{mg} / \mathrm{kg}$ PABA was administered to rats. In swine, a $5 \mathrm{mg} / \mathrm{kg}$ dose resulted in urinary PABA levels which were approximately 30 times higher than the background levels. These doses were then selected as the dose of the test peptide, in terms of PABA content, to be administered to each animal. The 100-fold differential in the rat was particularly advantageous because of the small urine volumes obtained from this species.

The peptides chosen for evaluation in rats and swine are shown in Table II. Each was hydrolyzed to a greater extent by the normal animals than by the pancreatic-deficient animals. The amount of PABA in the urine of the PDL swine dosed with each of these peptides was not significantly higher than background. However, this was not true in the case of the B-PDL rat in which recoveries approaching $30 \%$ of the dose were noted for some peptides.

Incubation of each of these peptides with chymotrypsin under identical conditions showed that the rate of hydrolysis of N-bz-L-tryptophanyl-PABA was $0.32 \mu \mathrm{moles} / \mathrm{min} / \mathrm{mg}$ enzyme (Table II) which was approximately $20 \%$ higher than that for N-bz-L-tyrosyl-PABA and twice that of N-bz-Lphenylalanyl-PABA.

The $\mathrm{N}$-acetyl and $\mathrm{N}$-propionyl analogs were slowly hydrolyzed $(0.02$ and $0.05 \mu \mathrm{moles} / \mathrm{min} / \mathrm{mg}$ enzyme). The relative rates of hydrolysis in vitro bore little relationship to the tests in vivo in which the N-benzoyl peptides generally resulted in somewhat lower urinary PABA levels in the control animals than did those having acetyl blocking groups. At this point it was decided to select N-bz-L-tyrosyl-

\begin{tabular}{|c|c|c|c|c|c|}
\hline \multirow{2}{*}{$\begin{array}{l}\text { Compound } \\
\text { Administered }\end{array}$} & \multirow{2}{*}{$\begin{array}{l}\text { Chymotrypsin } \\
\text { Assay }\end{array}$} & \multicolumn{2}{|l|}{ Rats } & \multicolumn{2}{|l|}{ Swine } \\
\hline & & Control & $B-P D L$ & Control & $P D L$ \\
\hline $\begin{array}{l}\text { PABA } \\
\text { N-bz-L-tyr-PABA } \\
\text { N-ac-L-tyr-PABA } \\
\text { N-prop-L-tyr-PABA } \\
\text { N-but-L-tyr-PABA } \\
\text { N-et-O-CO-L-tyr-PABA } \\
\text { N-bz-L-trypt-PABA } \\
\text { N-bz-L-phe-PABA }\end{array}$ & $\begin{array}{l}- \\
0.26 \\
0.02 \\
0.05 \\
0.14 \\
0.05 \\
0.32 \\
0.15\end{array}$ & $\begin{array}{l}62.1 \pm 3.4(9)^{3} \\
56.5 \pm 3.4(6) \\
77.9 \pm 1.6(4) \\
68.8 \pm 1.7(4) \\
67.3 \pm 2.8(4) \\
64.9 \pm 6.5(4) \\
33.0 \pm 3.1(4) \\
74.7 \pm 3.0(4)\end{array}$ & $\begin{array}{r}75.2 \pm 4.5(9) \\
9.1 \pm 2.0(6) \\
23.4 \pm 1 \cdot 2(4) \\
29.5 \pm 4.4(4) \\
11.0 \pm 0.6(4) \\
6.9 \pm 0.8(4) \\
12.7 \pm 2.2(4) \\
27.2 \pm 1.8(4)\end{array}$ & $\begin{array}{l}67.0 \pm 7.6(5) \\
24.5 \pm 6.5(7) \\
44.4 \pm 12.1(3) \\
46.3 \pm 6.1(3) \\
47.1 \pm 5 \cdot 1(3) \\
39.1 \pm 2.2(2) \\
18.6 \pm 2.7(7) \\
20.5 \pm 4.5(5)\end{array}$ & $\begin{array}{r}48.5 \pm 4.3(5) \\
0.8 \pm 0.4(4) \\
4.1 \pm 0.5(4) \\
2.5 \pm 0.5(4) \\
2.9 \pm 0.7(4) \\
2.2 \pm 0.4(4) \\
3.0 \pm 0.5(4) \\
3.4 \pm 0.2(2)\end{array}$ \\
\hline
\end{tabular}

Table II Recovery of PABA in urine following the oral administration of PABA-containing peptides

${ }^{1}$ Dosed at $10 \mathrm{mg} / \mathrm{kg}$ and $5 \mathrm{mg} / \mathrm{kg}$ PABA equivalents to rats and swine, respectively. All compounds were given as the sodium salt in $4 \mathrm{ml} \mathrm{H}_{z} \mathrm{O}$ (rats) and $50 \mathrm{ml} \mathrm{H} \mathrm{H}_{2} \mathrm{O}$ (swine).

Abbreviations: PABA, p-aminobenzoic acid; bz, benzoyl; ac, acetyl; prop, propionyl; but, butyryl; et-O-CO, ethoxycarbonyl; trypt, tryptophan; phe, phenylalanine; B-PDL, common bile duct ligated; PDL, pancreatic duct ligated.

$2 \mu$ moles PABA released/min/mg chymotrypsin. Refer to Methods for assay procedure.

${ }^{3}$ Percentage of administered PABA recovered in urine during the six hours after dose. Mean \pm SEM of the number of animals in parentheses. 
PABA for further investigation. The selection of this peptide was based upon both its rate of hydrolysis by chymotrypsin in vitro, and the ability of the peptide to differentiate between normal and pancreatic-deficient animals. N-bz-L-tyrosyl-PABA was evaluated in dogs, and the urinary recovery of PABA was $63.0 \pm 3.5 \%$ in control and $3.8 \pm 0.6 \%$ in the PDL animals. A summary of the results in vivo with N-bz-L-tyrosyl-PABA is shown in Table III. The difference in PABA recovery between control and pancreatic-deficient animals was highly significant $(P<0.01)$ for each animal species.

\begin{tabular}{llc}
\hline Species & \multicolumn{2}{l}{ Recovery of PABA in Urine } \\
\cline { 2 - 3 } & Control & Pancreatic Deficient $^{2}$ \\
\hline Rat & $56.5 . \pm 3.4(6)^{3}$ & $9.1 \pm 2.0(6)$ \\
Swine & $24.5 \pm 6.5(7)$ & $0.8 \pm 0.4(4)$ \\
Dog & $63.0 \pm 3.5(27)$ & $3.8 \pm 0.6(19)$ \\
\hline
\end{tabular}

Table III Recovery of PABA in urine following the oral administration of $N$-benzoyl-L-tyrosyl-PABA to normal and pancreatic-deficient animals

${ }^{1}$ As a percentage of the dose recovered in six hours. The peptide was administered at a dose of $5 \mathrm{mg} / \mathrm{kg}$ PABA equivalents to dogs and swine and $10 \mathrm{mg} / \mathrm{kg}$ PABA equivalents to rats.

${ }^{2}$ Common duct ligated rats; pancreatic duct ligated swine and dogs.

Mean \pm 1 SEM of the number of animals in parentheses.

The recovery of PABA in the urine of three BDL rats administered N-bz-L-tyrosyl-PABA was somewhat less than that observed in normal control rats $(35.4 \pm 5.0 \%$ vs $56.5 \pm 3.4 \%)$ but was significantly higher $(\mathrm{P}<0.01)$ than that of B-PDL rats.

When the cumulative percentage recovery of PABA in the urine collected at intervals following the administration of N-bz-L-tyrosyl-PABA to control animals was plotted (Fig. 1), it was found that the rates of PABA excretion were much greater by the dog and the rat than by the swine. However, within 24 hours following administration approximately $80-90 \%$ of the administered peptide-PABA was recovered from each animal species.

The difference in rates of PABA excretion during the early hours after dosage was probably not related to differences in PABA clearance rates since an intravenous dose of sodium PABA was excreted more rapidly by swine than by dogs (Fig. 2).

In pancreatic-deficient rats and swine given oral doses of pancreatin with the peptide, there was a significant increase in the recovery of PABA in the urine (Table IV). In the swine, the pancreatin was administered with the peptide and again at two and four hours later. The $5 \mathrm{~g}$ pancreatin dose ( $15 \mathrm{~g}$ total) raised PABA recoveries to levels which were as high as those seen in normal swine.

Studies were carried out to determine if the proposed pancreatic function test was sufficiently

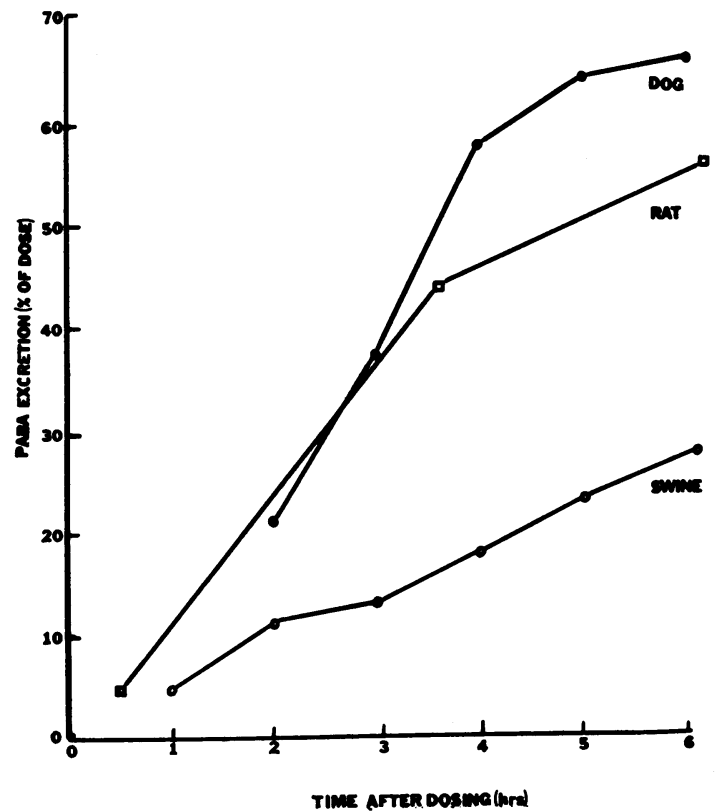

Fig. 1 Cumulative recovery of $P A B A$ in urine as a percentage of the oral dose of $N$-benzoyl-L-tyrosyl-PABA (dogs and swine received $155 \mathrm{mg} /$ animal, rats received $7.75 \mathrm{mg}$ each). Each point is the mean of one to five urine samples.

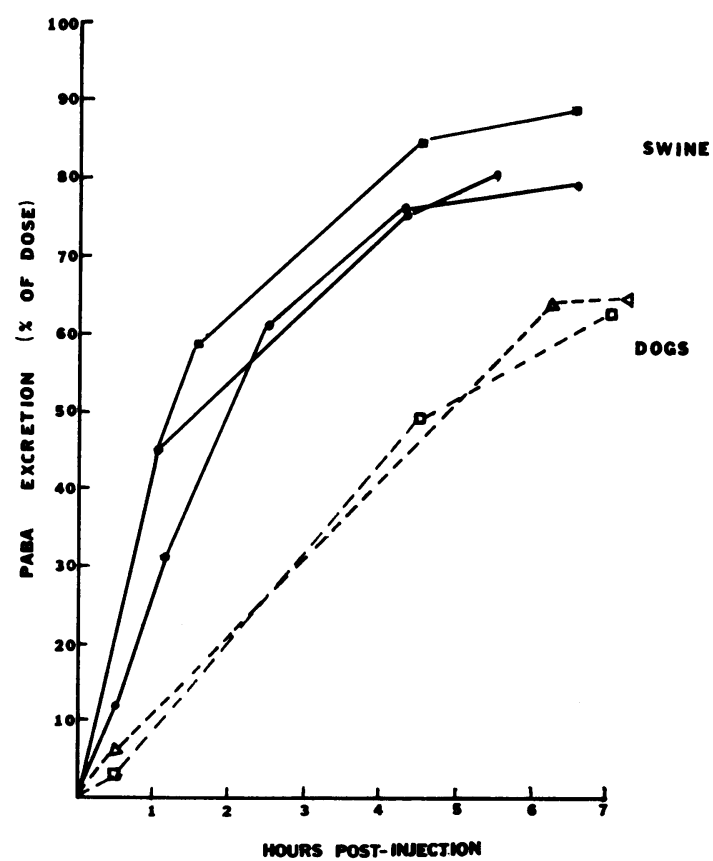

Fig. 2 Cumulative recovery of $P A B A$ in urine of two dogs and three swine following an intravenous dose of $50 \mathrm{mg}$ PABA each. 


\begin{tabular}{llcc}
\hline Animal & Treatment & $\begin{array}{l}\text { No. of } \\
\text { Animals }\end{array}$ & $\begin{array}{l}\text { Percentage of } P A B A^{2} \\
\text { Excreted }\end{array}$ \\
\hline B-PDL rats & 500 mg casein & 4 & $2 \cdot 2 \pm 0.6$ \\
& 10 mg pancreatin & 5 & $16.8 \pm 3.7^{1}$ \\
PDL swine & Control & 12 & $4.9 \pm 0.8$ \\
& 0.5 g pancreatin & 9 & $16.0 \pm 4 \cdot 0^{1}$ \\
& 1.0 g pancreatin & 10 & $19.4 \pm 2.4^{2}$ \\
& 2.5 g pancreatin & 10 & $29.6 \pm 4.4^{2}$ \\
& 5.0 g pancreatin & 10 & $36.9 \pm 4.0^{2}$ \\
\hline
\end{tabular}

Table IV Effect of orally administered pancreatin on the urinary excretion of $P A B A$ by pancreatic deficient animals dosed with $N$-benzoyl-L-tyrosyl-PABA

${ }^{1} \mathrm{~B}-\mathrm{PDL}$, common bile duct ligated; PDL, pancreatic duct ligated. 'Single doses of casein and pancreatin given at the time of peptide (10 $\mathrm{mg} / \mathrm{kg}$ PABA equivalents) administration to rats. In swine this dose of pancreatin was given three times-at the time of peptide (50 $\mathrm{mg} / \mathrm{swine}$ PABA equivalents) administration, then again at two and four hours later. The 12 controls represent three PDL swine receiving casein at a dose equal in weight to that of each of the four pancreatin doses.

Amount of PABA as percentage of the dose recovered in the urine during the six hours following the administration of the peptide. Values are means \pm 1 SEM. Different from control $\left({ }^{1} P<0.05 ;{ }^{2} P<0.01\right)$.

sensitive to differentiate between varying degrees of exocrine pancreatic insufficiency. Rats were made partially pancreatic deficient by surgically removing portions of the pancreas on the day before testing. The results of the individual tests are plotted in Fig. 3 with the amount of pancreas removed expressed as a percentage of the body weight. The control (sham-operated) rat excreted $54 \%$ of the PABA administered as peptide. In two rats in which total pancreatectomy was attempted, the amount of pancreas removed was greater than $0.06 \%$ of their body weights and the urinary excretion of PABA in these animals indicated that there was total pancreatic insufficiency. In the remaining rats, the test results indicated some degree of exocrine pancreatic deficiency.

Similar results were obtained in a second group of rats in which the common duct was ligated at various distances from its communication with the gut. The pancreatic function test was administered the following day, and the percentage of PABA recovered in the urine was plotted against the length of functional duct (Fig. 4). The results of this study were similar to those in the pancreatectomized rats in that the pancreatic function test was sensitive to the extremes resulting in a highly significant $(P<0.01)$ correlation coefficient when all the data were considered. However, the results obtained in the rats having intermediate lengths of functioning duct were, more or less, semi-quantitative in that they indicated that there was some degree of pancreatic enzyme deficiency.

N-bz-L-tyrosyl-PABA was also found to be resistant to attack by purified preparations of trypsin

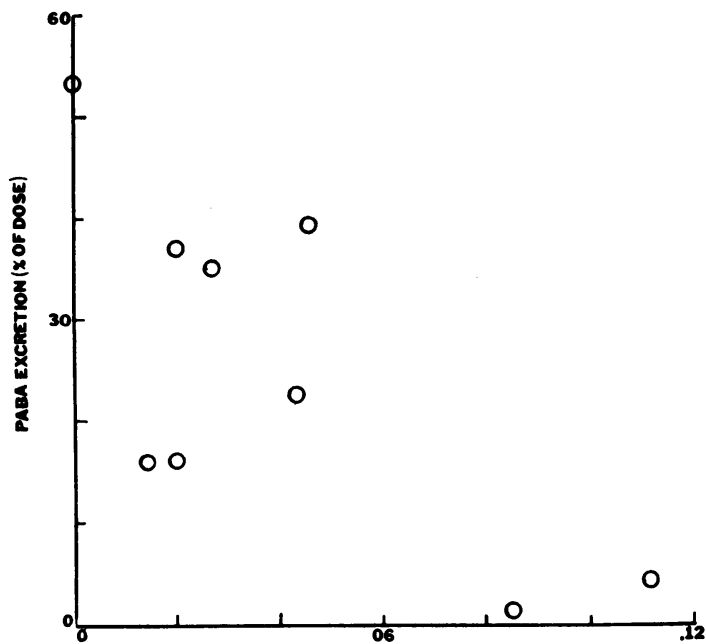

Fig. 3.

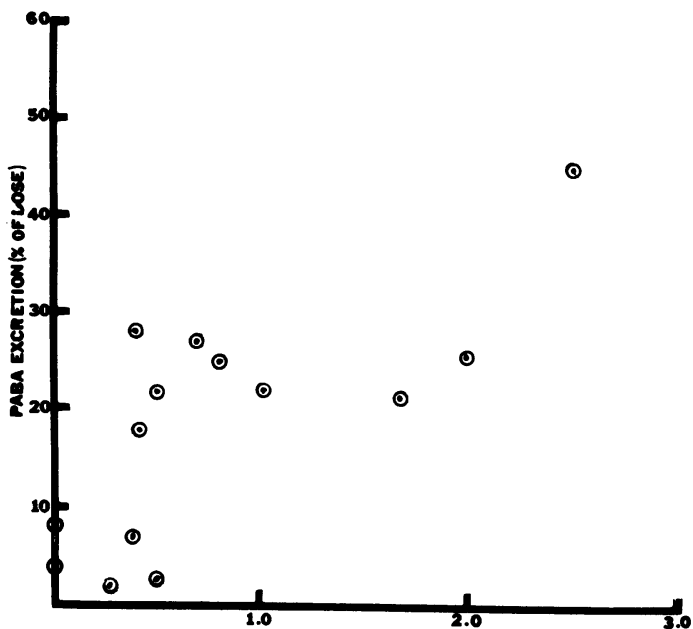

LENGTH OF PUNTIONAL DUCT $(\mathrm{cm})$

Fig. 4

Fig. 3 Recovery of PABA in urine during the six hours following an oral dose of $N$-benzoyl-L-tyrosyl-PABA (10 $m g / k g P A B A$ equivalents) to rats with partial pancreatic resection.

Fig. 4 Recovery of PABA in urine during the six hours following an oral dose of $N$-benzoyl-L-tyrosyl-PABA (10 $\mathrm{mg} / \mathrm{kg} P A B A$ equivalents) to rats in which the common duct was ligated at various distances from its communication with the small intestine. 
(Calbiochem) and carboxypeptidase A $(5 \times$ crystallized, Pentex Biochemical). Both enzyme preparations were shown to be highly active when incubated with their known substrates, N-benzoylarginine ethyl ester for trypsin and hippurinyl-L-phenylalanine for carboxypeptidase A.

Other studies demonstrated that N-bz-L-tyrosylPABA was resistant to pepsin in vitro and was hydrolyzed by $6 \mathrm{~N} \mathrm{HCl}$ only when heated at $100^{\circ}$ for one hour. When the peptide was administered orally to pyloric-ligated rats there was no significant increase in urinary PABA during the subsequent six hours. In contrast, the oral administration of sodium PABA to the pyloric-ligated rat caused a six-fold increase in urinary PABA levels. Similar results were obtained when either the peptide or sodium PABA were administered intracaecally, via a ventral mid-line incision, to the pancreatic-deficient rat. Under these conditions there was only moderate degradation of the peptide which resulted in urinary excretion of approximately $10 \%$ of the PABA during the six hours after treatment. More than $50 \%$ of an intracaecal dose of sodium PABA was recovered.

\section{Discussion}

The studies reported by Grossman (1962) using dogs having pancreatic exclusion and those reported by Ventzke, Davidson, and Grossman (1964) in patients suggested that measurement of chymotrypsin secretion may be more reliable than measurement of either trypsin or lipase secretion in the assessment of exocrine pancreatic function. Haverback, Dyce, Gutentag, and Montgomery (1963), and Ammann and Kashiwagi (1966) reported that faecal chymotrypsin determinations were useful in the diagnosis of pancreatic insufficiency. In later studies, Ammann, Tagwercher, Kashiwagi, and Rosenmund (1968) suggested the use of faecal chymotrypsin assays as a screening method for chronic pancreatitis and cancer of the head of the pancreas. Goldberg and Wormsley (1970) have also stressed the importance of measuring pancreatic protease secretion in the diagnosis of pancreatic disease.

The pancreatic function test described in the present communication is, in essence, an indirect test for chymotrypsin secretion. In this respect it differs from the protein tolerance tests (West, Wilson, and Eyles, 1946; Christensen and Shwachman, 1949; Chinn, Lavik, Stitt, and Buckaloo, 1952) which are measures of total intraluminal proteolysis. The present test also differs from the protein tolerance tests in that the hydrolytic product being measured is PABA, which is not a major body conscituent as are amino acids and peptides. Therefore, changes in protein metabolism are less likely to affect the present diagnostic procedure.

Although hydrolysis of N-bz-L-tyrosyl-PABA by enzymes other than chymotrypsin has not been completely ruled out, it is known to be resistant to pepsin, trypsin, and carboxypeptidase A. The results obtained following intracaecal administration of the peptide also indicate that it is not rapidly degraded by microflora in the lower bowel.

There was a somewhat lower recovery of PABA in the BDL rats dosed with N-bz-L-tyrosyl-PABA as compared to that in normal control rats which may have been due to some trauma caused to the pancreas during surgery. However, this experiment served to demonstrate that bile was not required for the intraluminal hydrolysis of the peptide, but that pancreatic juice was necessary. In this respect, the present test differs markedly from the tubeless pancreatic function test described by Kaffarnik and Meyer-Bertenrath (1970) in which fluorescein diesters are administered orally. These substrates are hydrophobic and require both bile and pancreatic lipase for splitting.

In addition to chymotrypsin specificity and the relative ease of performing the test, the fact that this test uses a well defined synthetic peptide and a relatively uncomplicated analytical method should make the procedure amenable to standardization among clinical laboratories. These characteristics are especially important because a lack of procedural standardization and variations in quality and purity of diagnostic materials have been suggested as being responsible for some of the unfavourable results obtained with the starch tolerance test (Althausen and Uyeyama, 1961) and with the ${ }^{131}$ I-triolein test (Cox, 1961; Tuna, Mangold, and Mosser, 1963; Kennedy and Kinloch, 1964).

A procedure requiring analysis of urinary aromatic amines, which are not readily degraded on standing, may offer an advantage over those techniques requiring enzyme assays, since the latter are more likely to be influenced by variations in handling samples and preservation.

The measurement of pancreatic bicarbonate and enzyme levels in the duodenum is generally considered to give a reliable assessment of exocrine pancreatic function (Wormsley, 1970). Whether or not the newly proposed pancreatic function test will have the sensitivity required to detect intermediate degrees of pancreatic dysfunction will not be known until it is evaluated in man. However, the results obtained in animal studies suggest that the basic idea of using a chymotrypsin-specific peptide with a readily absorbable and renally cleared tracer group as a pancreatic function test is sound and warrants further study. 
We are grateful to Dr Norton Greenberger of The Ohio State University for his ideas which initiated these studies and for his encouragement throughout the course of this work. A special note of appreciation is also extended to Dr Peter de Benneville of the Rohm and Haaas Company for synthesis of the peptides and to Dr Samuel Gusman and Dr Theodore G. Brown Jr of Warren-Teed Pharmaceuticals for their helpful suggestions. We also wish to thank Mr Theodore Green and members of the Department of Clinical Chemistry for their technical assistance.

\section{References}

Althausen, T. L., and Uyeyama, K. (1961). Further experience with the starch tolerance test for pancreatic insufficiency. Gastroenterology, 40, 470-471.

Ammann, R., and Kashiwagi, H. (1966). Pancreatic exocrine insufficiency and proteolytic enzymes in stool: a critical evaluation of a new diagnostic test in various forms of steatorrhea. Helv. med. Acta, 33, 220-228.

Ammann, R. W., Tagwercher, E., Kashiwagi, H., and Rosenmund, H. (1968). Diagnostic value of fecal chymotrypsin and trypsin assessment for detection of pancreatic disease. Amer. J. dig. Dis., 13, 123-146.

Chinn, A. B., Lavik, P. S., Stitt, R. M., and Buckaloo, G. W. (1952). Use of $I^{131}$-labeled protein in the diagnosis of pancreatic insufficiency. New Engl. J. Med., 247, 877-880.

Christensen, H. N., and Shwachman, H. (1949). Determination of the plasma glycine after gelatin feeding as a diagnostic procedure for pancreatic fibrosis. J. clin. Invest., 28, 319-321.
Cox, A. G. (1961). Assessment of the radiotriolein test in steatorrhea. Brit. med. J., 2, 933-938.

Goldberg, D. M., and Wormsley, K. G. (1970). The interrelationships of pancreatic enzymes in human duodenal aspirate. Gut, 11, 859-866.

Grossman, M. I. (1958). Pancreatic secretion in the rat. Amer. J. Physiol., 194, 535-539.

Grossman, M. (1962). Fecal enzymes of dogs with pancreatic exclusion. Proc. Soc. exp. Biol. (N.Y.), 110, 41-42.

Haverback, B. J., Dyce, B. J., Gutentag, P. J., and Montgomery, D. W. (1963). Measurement of trypsin and chymotrypsin in stool. Gastroenterology, 44, 588-597.

Imondi, A. R., Stradley, R. P., Wolgemuth, R., and Brown, T. G. (1971). A new test for exocrine pancreatic function. (Abstr.) Pharmacologist, 13, 290.

Kaffarnik, H., and Meyer-Bertenrath, J. G. (1970). Bestimmung von Esteraseaktivitäten in vivo mit dem neuen Substrat Fluoresceindilaurinsäureester. Arzneim-Forsch., 20, 754-756.

Kennedy, J. A., and Kinloch, J. D. (1964). The impurity of radioiodinated triolein. J. clin. Path., 17, 160-162.

Pekas, J. C., Hays, V. W., and Thompson, A. M. (1964). Exclusion of the exocrine pancreatic secretion: effect on digestibility of soybean and milk protein by baby pigs at various ages. J. Nutr., 82, 277-286.

Smith, H. W., Finkelstein, N., Aliminosa, L., Crawford, B., and Graber, M. (1945). The renal clearance of substituted hippuric acid derivatives and other aromatic acids in dog and man. J. clin. Invest., 24, 388-404.

Tuna, N., Mangold, H. K., and Mosser, D. G. (1963). Re-evaluation of the $\mathrm{I}^{231}$-triolein absorption test. J. Lab. clin. Med., 61, 620-628.

Ventzke, L. E., Davidson, W. A., and Grossman, M. I. (1964). Diagnostic value of pancreatic enzyme response to a test meal. (A.G.A. Abstr.). Gastroenterology, 46, 765.

West, C. D., Wilson, J. L., and Eyles, R. (1946). Blood amino nitrogen levels. Amer. J. Dis. Child., 72, 251-273.

Wormsley, K. G. (1970). Tests of pancreatic function. Scand. $J$. Gastroent., 5, 1-3. 